УДК 349.2

В. М. Павліченко

\title{
НАПРЯМИ ГАРМОНІЗАЦІЇ НАЦІОНАЛЬНОГО НОРМАТИВНО-ПРАВОВОГО ЗАБЕЗПЕЧЕННЯ ПРАЦІ ДЕРЖАВНИХ СЛУЖБОВЦІВ ІЗ ЗАКОНОДАВСТВОМ КРАЇН ПОСТРАДЯНСЬКОГО ПРОСТОРУ
}

Актуальність проблеми. Оскільки Україна перебуває на стадії реформування законодавства у сфері праці суддів і поступової демократизації суспільства, необхідним є виділення напрямів гармонізації національного законодавства у сфері праці державних службовців із законодавством пострадянських країн. Урахування всіх особливостей гармонізації у сфері праці державних службовців дає підстави сподіватись на подальші позитивні зміни в підходах до нормотворення, що сприятиме підвищенню результативності здійснення реформ у цьому напрямі.

Стан дослідження проблеми. Проблематиці визначення напрямів оптимізації законодавчої техніки гармонізації національного нормативно-правового забезпечення праці державних службовців із законодавством країн пострадянського простору більшою чи меншою мірою приділяли увагу такі науковці, як В.Б. Авер'янов, Д.М. Бахрах, Ю.П. Битяк, Н.Б. Болотіна, О.В. Валецька, С.О. Грибань, М.І. Іншин, М.М. Клемпарський, С.О. Кохан, О.Ю. Оболенський, В.М. Павліченко, П.Д. Пилипенко, О.М. Петров, С.М. Прилипко, В.І. Прокопенко, О.І. Процевський, Г.Д. Стратієнко, I.Є. Чорнобиль, О.М. Ярошенко та інші.

Метою статті $€$ визначення шляхів оптимізації законодавчої техніки гармонізації національного нормативно-правового забезпечення праці державних службовців із законодавством країн пострадянського простору.

Основний зміст роботи. Першим напрямом гармонізації національного законодавства у сфері праці державних службовців із законодавством країн пострадянського простору $€$ оновлення моделі праці державних службовців. Країнам - членам СРСР був притаманний демократичний централізм у сфері правового регулювання праці державних службовців. Як зазначає О. М. Куракін, вищі органи мають повноваження владного волевиявлення стосовно нижчих. При цьому керівництво вищих органів тру- 
доправовою діяльністю нижчих має як загальний, директивний характер, так і безпосередній, оперативний. Здійснюється воно з метою досягнення точного та неухильного виконання законів та інших нормативних актів, перетворення в трудовій діяльності державних службовців політики народу, забезпечення єдиних форм і методів роботи в усіх основних напрямах. Підпорядкування нижчого органу має імперативний характер, а обов'язок виконувати розпорядження вищого органу є основним елементом їх взаємовідносин [1, с. 19-20].

Варто погодитись із вченим, адже справді, не тільки Україні, а й іншим державам - колишнім членам СРСР все ще притаманний демократичний централізм, на основі якого були збудовані майже всі політико-правові інститути. Суть цього принципу полягає в підконтрольності та підзвітності працівників певному центру, а також у виконанні наданих ним завдань. Варто зазначити, що вплив з боку демократичного централізму на працю державних службовців проявляється у встановленні ієрархічно-структурованої системи посад державних службовців. Кожен державний службовець нижчої ланки чи посади виконує свою трудову функцію під чітким керівництвом державного службовця вищої ланки чи посади. Проте усі державні службовці здійснюють свою трудову діяльність, керуючись вказівками відповідного центру.

Цілеспрямоване реформування національного законодавства щодо праці державних службовців є наступним напрямом гармонізації національного законодавства із законодавством країн пострадянського простору. Його суть полягає в необхідності позбутися застарілих підходів до визначення праці державних службовців та в запозиченні інноваційних конструктивних тенденцій оптимізації робочого процесу державних службовців.

Особливістю визначення трудоправового статусу державних службовців є притаманний переважній більшості країн пострадянського простору адміністративно-правовий підхід до визначення діяльності працівників державної служби. Це зумовлює здійснення правового регулювання праці державних службовців в основному нормами адміністративного права. Саме тому більшість країн колишнього СРСР у профільних законах (Закон України «Про державну службу» [2], Закон Казахстану «Про державну службу» [3], Закон Республіки Білорусі «Про державну службу» [4], Федеральний Закон «Про державну службу РФ»[5], Закон Литовської Республіки «Про державну службу» [6] тощо) про державну службу визначають статус державного службовця як адміністративно-правовий, а статус останнього як суб'єкта трудового права врегульовується кодифікованими актами трудового законодавства кожної конкретної країни.

Третім напрямом приведення національного законодавства у відповідність до норм, що встановлюють пострадянські країни у сфері праці державних службовців, є перейняття досвіду запровадження активної антикорупційної політики в цій сфері. Успішний досвід протидії та запобігання корупції у сфері праці державних службовців направляє національних законодавців до упорядкування та адаптації нормативно-правової бази в зазначеній сфері. 
Пострадянські країни входили, а деякі й досі входять до найкорумпованіших країн світу, тому більшість 3 них здійснюють активну антикорупційну політику в цій сфері й отримують успішний результат. Грузія досягла значного прогресу в зменшенні корупції, про що свідчать результати різних опитувань громадського сприйняття й міжнародні рейтинги. У 2010-2013 pp. уряд Грузії продовжив реалізацію важливих реформ, спрямованих на подальше зменшення рівня корупції. Законодавство Грузії було здебільшого приведено у відповідність до міжнародних стандартів щодо встановлення кримінальної відповідальності за корупційні правопорушення [7]. Щодо антикорупційних норм у сфері праці державних службовців, то глава 4 Закону Грузії «Про публічну службу» визначає обов'язки та обмеження, що містять у собі положення у сфері протидії та запобігання корупції в державних та місцевих органах [8]. Взаємообмін позитивним досвідом у цій сфері забезпечує створення належних умов щодо недопущення корупційних проявів у праці державних службовців. Такі заходи здійснюються шляхом встановлення достойної заробітної плати, різних гарантій і компенсацій для державних службовців, а також просвітницької діяльності, яка направлена на осмислення державними службовцями того, що корупційні правопорушення під час здійснення ними своєї трудової діяльності є невигідними і загрожують як їх матеріальному становищу, так і майбутній трудовій діяльності в певному державному органі або в органі місцевого самоврядування.

Як відзначає В.В. Побережний, однією з основних причин корупції серед державних службовців є низький рівень оплати праці та надання соціальних послуг [9, с. 4]. Тому важливим аспектом у вдосконаленні праці державних службовців та забезпечення антикорупційної політики $є$ адекватне оцінювання трудової діяльності таких працівників і встановлення мінімальних гарантій достойної заробітної плати, які направлені на створення необхідного матеріального становища державних службовців. Більше того, проведення семінарів і бесід щодо негативного впливу корупції на трудоправове становище працівників державної служби дасть змогу змінити їх ставлення до такого соціально-правового явища.

Наступним напрямом гармонізації норм національного законодавства 3 нормами пострадянських країн $є$ поступова відмова від політизації праці державних службовців. У країн, що вийшли з СРСР, залишається політичний характер праці державних службовців. Це характерно для норм законодавства у сфері праці державних службовців в більшості країн, що пройшли радянський період. Політичні державні службовці впливають на адміністративних державних службовців, які їм підпорядковуються та беззаперечно виконують накази й розпорядження.

Як зазначає К.К. Баранцева, жорстке підпорядкування адміністративного апарату політичній еліті привело до того, що комуністичні країни будували свою державну службу не на принципі кар'єри, як більшість західних країн, а на принципі призначень [10, с. 24]. Враховуючи вищенаведене, необхідно зазначити, що такий метод використовується і на теперішній час. Національне законодавство передбачає саме призначення державних 
службовців, а не їх кар'єрний ріст. Такий підхід до регулювання праці державних службовців зумовлює виникнення корупційних проявів і призначення чи підвищення у посаді не за особливі заслуги перед державою за свою трудову діяльність, а за ступенем спорідненості чи наближеності до вищих посадових осіб - роботодавців. Проте напрям удосконалення трудових правовідносин у державній службі характеризується закріпленням статусу державного службовця як трудоправового, а також поступовим удосконаленням системи підвищення їхнього кар'єрного росту.

Наступним напрямом гармонізації законодавства у сфері праці державних службовців із законодавством пострадянських країн $є$ ухвалення нормативно-правових актів про створення регіональних і місцевих органів. У контексті трудового права цей аспект є позитивним, оскільки такі законодавчі реформи забезпечують створення додаткових робочих місць для майбутніх державних службовців. Більше того, для працівників державної служби це також створює можливість працювати та отримувати заробітну плату в територіальних межах місця їх проживання.

Доцільним є наведення прикладу досвіду Російської Федерації в цій сфеpi. Російська Федерація має розвинену систему місцевого самоврядування, що не входить до системи органів державної влади. Згідно зі ст. 131 Конституції РФ місцеве самоврядування здійснюється в міських, сільських поселеннях і на інших територіях з урахуванням історичних та інших місцевих традицій. Основні засади діяльності населення щодо здійснення місцевого самоврядування закріплюються в Конституції РФ, федеральних законах, законах суб̆'єктів РФ, інших нормативних актах (статути міст і районів, Закон міста Москви «Про районну управу в м. Москві» 1996 р., положення «Про збори громадян за місцем проживання», «Про старост, селищні й сільські округи») [11]. Створення ефективної системи державного управління на місцях $є$ результатом виконання країнами - членами колишнього СРСР Європейської хартії місцевого самоврядування [12]. Такі системи надають змогу врегульовувати трудові правовідносини державних службовців не тільки на загальнодержавному рівні, а й на локальному, місцевому, і деталізують окремі аспекти праці державних службовців у певних місцевих органах влади, враховуючи територіальне розташування, звичаї та інше. Ці заходи спрямовуються на поступову децентралізацію державного управління, а також на забезпечення зайнятістю державних службовців.

Наступним напрямом $є$ нормативно-правове закріплення права на працю в державній службі не тільки громадян України, а й іноземців. Варто зазначити, що вимога до наявності громадянства закріплена в національному законодавстві, у ст. 4 Закону України «Про державну службу» [2], і вона $є$ характерною для більшості пострадянських країн. Зокрема, у ст. 24 відповідного закону Республіки Білорусі зазначається, що право на державну службу мають громадяни Республіки Білорусі, які досягли 18-річного віку, володіють державною мовою Республіки Білорусі та відповідають іншим вимогам, встановленим цим законом, іншими законодавчими актами про державну службу [4]. 
Така ж вимога встановлюється ст. 16 Закону Грузії «Про публічну службу», у якій йдеться про те, що до кандидатів на посаду в публічній службі висуваються вимоги щодо наявності громадянства, володіння державною мовою, освіти не нижче середньої та досягнення 18-річного віку [8]. Визначення цієї умови вступу на державну службу впливає на розвиток праці в цих країнах. Необхідно зазначити, що деякі пострадянські країни на теперішній час надають право вступу на державну службу іноземцям, але у виняткових випадках, на чітко визначений перелік посад, які мають переважно адміністративний характер.

Також напрямом гармонізації національного законодавства у сфеpi праці державних службовців із законодавством колишніх членів СРСР є встановлення конкурсного відбору на посади. У ст. 24 Закону Казахстану «Про державну службу» передбачається конкурсний відбір на зайняття адміністративної посади [3]. Закон Молдови «Про державну службу» в ст. 14 також встановлює таку процедуру вступу на посаду державного службовця [13]. Законом Республіки Білорусі «Про державну службу» встановлюється конкурсний відбір, що передує вступу на державну посаду, а також випробувальний термін [4]. Російська Федерація також не є винятком і встановлює зазначену форму працевлаштування на державну службу в ст. 22 Федерального Закону «Про державну службу в РФ» [5].

Така норма закріплюється майже в усіх країнах пострадянського простору та створює передумови для набору до органів влади найкращих спеціалістів у сфері державної служби. За А.М. Олешко, чинна процедура іспиту та співбесіди не завжди сприяє кваліфікаційно-обгрунтованому визначенню відповідності конкурсантів особистим вимогам, які висувають до державних службовців [14, с. 121].

До заходів щодо приведення норм законодавства про працю державних службовців у відповідність до норм пострадянських країн слід також віднести забезпечення професійного навчання державних службовців і розвиток Школи вищого корпусу державної служби на основі досвіду колишніх країн-членів СРСР.

Постанова Уряду Російської Федерації від 13 вересня 1994 р. № 1047 «Про організацію перепідготовки та підвищення кваліфікації державних службовців федеральних органів виконавчої влади» визначає положення щодо правового регулювання перепідготовки та підвищення кваліфікації державних службовців федеральних органів, що здійснюється на основі державного замовлення [15]. У Білорусі основні положення щодо професійної підготовки, перепідготовки та підвищення кваліфікації затверджені Указом Президента Республіки Білорусь «Про деякі заходи щодо вдосконалення підготовки, перепідготовки та підвищення кваліфікації кадрів державної служби» [16]. Такі ж самі норми щодо професіоналізації праці державних службовців Казахстану визначаються в «Правилах підготовки, перепідготовки та підвищення кваліфікації державних службовців», затверджених Указом Президента [17]. 
Як зазначає $€$. І. Бородін, одним із основних принципів державної служби, зафіксованим в п. 5 ст. 3 Закону України «Про державну службу» [2], $є$ професіоналізм, що підкреслює високу суспільну значущість діяльності державних службовців. Стаття 1 Закону деталізує зміст категорії «професіоналізм» через поняття «рівень професійної компетентності особи» та «профіль професійної компетентності посади державної служби», ставлячи в центр уваги таку якість, як «професійна компетентність» [18, с. 15]. Указом Президента України було створено Українську академію державного управління при Президентові України, якій згодом було надано статус Національної академії [19].

Таким чином, у пострадянських країнах було встановлено нормативно-правове регулювання та запроваджено спеціальні заклади, щодо професійної підготовки, перепідготовки та підвищення кваліфікації державних службовців. Тенденція до розвитку трудового потенціалу працівників державної служби властива майже всім країнам пострадянського простору. Саме тому національне законодавство активно розвивається в цьому аспекті, запозичує досвід підготовки спеціалістів у сфері державної служби та створює нормативно-правове забезпечення діяльності щодо підвищення якості праці державних службовців.

Розвиток загальнонаціональної системи професійного навчання державних службовців має йти в напрямі зміцнення керованості діяльності системи, взаємозв'язку та координованості дій усіх навчальних закладів, що здійснюють освітню діяльність у сфері державної служби, з урахуванням відомчих видів (у межах гілок влади та структур їх органів) і рівнів [20, с. 43]. Тому задля забезпечення здійснення службовцями своїх трудових функцій їм необхідно постійно підтримувати та вдосконалювати свої знання з метою досягнення вищого ступеня професіоналізму.

Наступним напрямом гармонізації законодавства у сфері праці державних службовців із законодавством пострадянських країн $є$ створення ефективної електронної системи урядування на основі досвіду Естонської республіки. Як вказує О.О. Костюк, створення електронного уряду має забезпечити не тільки більш ефективне та менш затратне адміністрування, а й кардинальну зміну взаємовідносин суспільства з урядом. У результаті це приведе до вдосконалення демократії та підвищення відповідальності влади перед народом [21, с. 53].

За С.А. Чукут, створення такої системи характерне для більшості країн учасниць СРСР і зумовлене ефективністю іiі функціонування. Приведення національного законодавства у відповідність до цього напряму є однією з основних ознак гармонізаціі. Сучасна Естонська стратегія розвитку інформаційного суспільства будується відповідно до «і 2010: A European Information Society for growth and employment» та «i 2010 e Government action plan» (програма дій), затверджених урядом Естонії, і залучає до своєї реалізації всі міністерства, державну канцелярію, наукові кола та інші організації. Водночас нова стратегія «Estonian Information Society Strategy 2013» була схвалена і затверджена 30 листопада 2006 р. урядом Естонії 
та набула чинності 1 січня 2007 р. [22, с. 28]. На сьогодні електронна система Кабінету Міністрів Естонії дозволяє оперативно обмінюватися документами, ознайомлюватися з редакціями проектів нормативних актів і навіть проводити голосування.

Також зазначену тенденцію до впровадження електронної системи урядування можна побачити в Російській Федерації, Уряд якої прийняв відповідне розпорядження про формування системи електронного урядування [23]. Аналізуючи наведене, можна стверджувати, що функціонування цієі системи сприятиме оптимізації праці державних службовців, дозволить скоротити витрати та сприяти покращенню правового становища державних службовців як працівників.

Висновки. Отже, виходячи з вищевикладеного, можна дійти висновку, що пострадянські країни активно співпрацюють у сфері правових норм щодо оплати праці державних службовців. Більше того, удосконалення національного законодавства у сфері праці державних службовців передбачає підвищення заробітних плат державних службовців, встановлення низки гарантій і компенсацій праці з метою забезпечення останніми своїх суспільних потреб і недопущення проявів корупції. Встановлення гарантій щодо компенсацій різного роду витрат є ще однією, додатковою ознакою гармонізації законодавства у цій сфері.

Профільними законами про державну службу різних країн пострадянського простору встановлюються компенсації за витрати, пов'язані з відрядженням, інвалідністю, працю у вихідні тощо. Ця ознака свідчить про тенденцію до розширення прав державних службовців у сфері праці та закріплення їх на законодавчому рівні. Правове регулювання гарантій у праці державних службовців здійснюється за допомогою великої кількості нормативно-правових актів, що свідчить про спрямованість законодавства цих країн на всебічне соціальне та матеріальне забезпечення державних службовців.

\section{Література}

1. Куракін О.М. Теоретико-правові аспекти розвитку демократичного централізму в діяльності правоохоронних органів / О.М. Куракін / / Науковий вісник Дніпропетровського державного університету внутрішніх справ. - 2012. - № 3. - С. 18-23.

2. Про державну службу : Закон № 3723-XII від 16 грудня 1993 р. / Відомості Верховної Ради України (ВВР). - 1993. - № 52. - Ст. 490.

3. Мемлекеттік қызмет туралы Қазақстан Республикасының 1999 жылғы 23 шілдедегі № 453 Заңы / / [Електронний ресурс]. - Режим доступу : http:/ / adilet.zan.kz/kaz/docs/Z990000453.

4. О государственной службе в Республике Беларусь. Закон Республики Беларусь № 2043 от 14 июня 2003 г. [Електронний ресурс]. - Режим доступу : http://www.pravo.by/main. aspx? guid $=3871 \& \mathrm{p} 0=\mathrm{H} 10300204$

5. Федеральный закон от 27.07.2004 N 79-Ф3 (ред. от 5 октября 2015) «О государственной гражданской службе Российской Федерации» [Електронний ресурс]. - Режим доступу : https: / / www.consultant.ru/document/cons_doc_LAW_48601/.

6. Valstybès Tarnybos İstatymas 2011-12-23 Teisès aktą prièmè - Lietuvos Respublikos Seimas [Електронний ресурс]. - Режим доступу : http://www3.lrs.lt/pls/inter3/dokpaieska. showdoc_l?p_id=416572.

7. Третий раунд мониторинга. Грузия. Отчет о мониторинге. Стамбульский план действий по борьбе с коррупцией 25 сентября 2013 г. [Електронний ресурс]. - Режим доступу : http:/ / www.oecd.org/corruption/acn/ GEORGIAThirdRoundMonitoringReportRUS.pdf. 


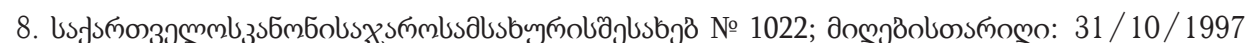
[Електронний ресурс]. - Режим доступу : https:// matsne.gov.ge/ka/document/view/28312.

9. Побережний В.В. Сутність та причини корупції в системі органів державної влади / В.В. Побережний / / Державне управління: теорія та практика. - 2010. - № 2. - [Електронний pecypc]. - Режим доступу : http://www.nbuv.gov.ua/e-journals/dutp/2010_2/txts/10pvvodv.pdf.

10. Баранцева К.К. Професіоналізація державної служби: зарубіжний досвід та досвід України / К.К. Баранцева / / Теорія і практика підвищення кваліфікації (аспекти державної податкової служби). - 2010. - № 1. - С. 8-30.

11. Камінська Н.В. Місцеве самоврядування. § 3. Основні засади організації місцевого самоврядування у пострадянських країнах / Н.В. Камінська / / [Електронний ресурс]. - Режим доступу : http:// westudents.com.ua/glavy/65496--3-osnovn-zasadi-organzats-mstsevogosamovryaduvannya-u-postradyanskih-kranah.html.

12. Європейська хартія місцевого самоврядування: Хартія, Міжнародний документ від 15 жовтня 1985 р. [Електронний ресурс]. - Режим доступу : http://zakon3.rada.gov.ua/laws / show /994_036.

13. Serviciului Public LEGE № 443 din 04.05.1995 [Електронний ресурс]. - Режим доступу : http: / / lex.justice.md $/$ index.php?action=view\&view=doc\&id=311669.

14. Олешко А.М. Конкурсний відбір та його вплив на формування якісного корпусу державних службовців / А.М. Олешко // Економіка та держава. - 2009. - № 7. - С. 118-121.

15. Постановление Правительства РФ от 13 сентября 1994 г. № 1047 (ред. от 23 октября 2001 г.) «Об организации переподготовки и повышения квалификации государственных служащих федеральных органов и сполнительной власти» [Електронний ресурс]. - Режим доступу : http: / / www.consultant.ru/document/cons_doc_LAW_4487.

16. О некоторых мерах по совершенствованию подготовки, переподготовки и повышения квалификации кадров в сфере управления : Указ Президента Республики Беларуси № 275 от 2 июня 2009 г. [Електронний ресурс]. - Режим доступу : http://www.pravo.by/main. aspx? guid $=3871 \& \mathrm{p} 0=\mathrm{P} 30900275$.

17. Правила подготовки, переподготовки и повышения квалификации государственных служащих Республики Казахстан : Указ Президента Республики Казахстан № 1457 от 11 октября 2004 г. [Електронний ресурс]. - Режим доступу : http:/ / tengrinews.kz/zakon/prezident_ respubliki_kazahstan/trud/id-U040001457.

18. Реформування професійного навчання державних службовців в Україні: проблеми та перспективи : [монографія] / С.М. Серьогін, Є.І. Бородін, Н.А. Липовська та ін. - К. : НАДУ, 2013. - 112 c.

19. Про систему підготовки, перепідготовки та підвищення кваліфікації державних службовців : Указ Президента України № 398/95 від 30 травня 1995 р. [Електронний ресурс]. - Режим доступу : http:// zakon5.rada.gov.ua/laws/show/167-97-\%D0\%BF.

20. Мельников О.В. Проблеми професійної підготовки державних службовців та перспективи їх вирішення / О.В. Мельников [Електронний ресурс]. - Режим доступу : http://www. kbuapa.kharkov.ua/e-book/putp/2011-2/doc/1/07.pdf.

21. Костюк О.О. Створення мультисервісної Національної телекомунікаційної мережі в рамках розвитку електронного урядування / О.О. Костюк, Д.В. Чуприна [Електронний ресурс]. Режим доступу : http://www.ekmair.ukma.edu.ua/bitstream/handle/123456789/6716/ Kostyuk_Stvorennya_mul'tyservisnoyi_natsional'noyi.pdf? sequence=1 \&isAllowed=y.

22. Зарубіжний досвід упровадження електронного урядування / авт. кол. : Т. Камінська, А. Камінський, М. Пасічник та ін. ; за заг. ред. д-ра наук з держ. упр., проф. С.А. Чукут. - К., 2008. -200 c.

23. Концепция формирования в Российской Федерации электронного правительства до 2010 года : одобрена распоряжением Правительства Российской Федерации № 632-р от 6 мая 2008 г. [Електронний ресурс]. - Режим доступу : http://www.consultant.ru/document/cons_doc_ LAW_76942/. 


\section{Анот а ці я}

Павліченко В. М. Напрями гармонізації національного нормативно-правового забезпечення праці державних службовців із законодавством країн пострадянського простору. - Стаття.

У статті визначено поняття «оптимізація законодавчої техніки гармонізації національного нормативно-правового забезпечення праці державних службовців із законодавством країн пострадянського простору». Сформульовано напрями оптимізації законодавчої техніки гармонізації національного нормативно-правового забезпечення праці державних службовців із законодавством країн пострадянського простору та наведено механізм їх реалізації.

Ключові слова: законодавча техніка, оптимізація законодавчої техніки, гармонізація, нормативно-правове забезпечення праці державних службовців, оптимізація законодавчої техніки гармонізації національного нормативно-правового забезпечення.

\section{А н н о т а ци я}

Павличенко В. H. Направления гармонизации национального нормативно-правового обеспечения работы государственных служащих с законодательством стран постсоветского пространства. - Статья.

В статье определено понятие «оптимизация законодательной техники гармонизации национального нормативно-правового обеспечения работы государственных служащих с законодательством стран постсоветского пространства». Сформулированы направления оптимизации законодательной техники гармонизации национального нормативно-правового обеспечения работы государственных служащих с законодательством стран постсоветского пространства и приведены механизмы их реализации.

Ключевые слова: законодательная техника, оптимизация законодательной техники, гармонизация нормативно-правовое обеспечение работы государственных служащих, оптимизация законодательной техники гармонизации национального нормативно-правового обеспечения.

\section{S u m m a r y}

Pavlichenko V. M. Areas of harmonization of the national regulatory framework of the work of civil servants from the former Soviet Union countries legislation. - Article.

The article defines the concept of "optimization of the legislative technique of harmonization of national regulatory framework of the work of public servants with post-Soviet countries the legislation". Directions of optimization legislative technique of harmonization of national regulatory framework of the work of public servants with the legislation of the former Soviet Union countries are formulated and provides a mechanism for their implementation.

Key words: legal advice, optimization of legislative technique, harmonization of regulatory support of civil servants, optimization of legislative technique of harmonization of national regulatory support. 